\title{
MENINGKATKAN KEMANDIRIAN ANAK UDIA DINI MELALUI METODE SOSIODRAMA BERBASIS CTL (CONTEXTUAL TEACHING LEARNING)
}

\author{
Sri Kartini Dewi $\mathrm{A}^{1}$ \\ Nenden Ineu Herawati ${ }^{2}$ \\ Lely Halimah ${ }^{3}$
}

\begin{abstract}
ABSTRAK
Penelitian ini atas dasar permasalahan kemandirian anak yang sering dihadapi oleh guru dikelas A TK Smart Kindergarten, antara lain: anak belum mampu menyiapkan perlengkapan makan dengan mandiri, anak belum mampu mengambil makanan yang akan dimakan dengan sendiri, anak belum mampu membereskan perlengkapan makan dengan sendiri dan masih membutuhkan bantuan. Untuk mengatasi permasalahan tersebut yaitu dengan penerapan metode sosiodrama berbasis CTL dalam pembelajaran pembiasaan anak sejak usia dini. metode sosiodrama berbasis CTL merupakan kolaborasi dari sosiodrama dan CTL. Metode sosiodrama adalah suatu cara memerankan beberapa peran dalam suatu cerita tertentu yang menuntut integrasi di antara pemerannya. Metode sosiodrama berbasis CTL yang diperankan atau didramatisasikan oleh anak memuat suatu kejadian atau contohcontoh yang biasa ditemukan dalam kehidupan sehari-hari anak. untuk rumusan masalahnya yaitu: (1) Bagaimana aktivitas kemandirian anak melalui metode sosiodrama berbasis CTL. (2) Bagaimana peningkatan kemandirian anak setelah diterapkannya metode sosiodrama berbasis CTL (3) Bagaimana lingkungan yang kondusif untuk meningkatkan kemandirian anak usia dini. metode penelitian yang digunakan adalah metode penelitian tindakan kelas (PTK), dengan menggunakan desain penelitian dari John Elliot. PTK ini dilaksanakan dalam tiga siklus, dengan satu siklus sebanyak tiga tindakan. Tekhnik pengumpulan data yang digunakan meliputi instrumen penilaian performa, observasi, wawancara, catatan lapangan dan dokumentasi berupa foto. Penelitian ini menunjukkan kemandirian anak mengalami peningkatan pada aktivitas kegiatan makan bersama yaitu anak mampu melakukan kegiatan dengan sendiri dari awal mempersiapkan makanan hingga membereskan perlengkapan makan tanpa dibantu. Pada hasil penelitian yang diperoleh mengalami perkembangan yang cukup signifikan setiap siklusnya. Berdasarkan data yang diperoleh pada siklus I dari ketiga indikator dari keseluruhan anak yang mendapatkan bintang empat anak mampu menyiapkan perlengkapan makan, anak mampu mengambil makanan, dan anak mampu memberekan peralatan makan hasil perkembangan kemandirian anak menunjukkan hasil 33,33\%, siklus II sebesar 48.14\%, dan siklus III menunjukkan hasil $85,18 \%$. Hal tersebut dapat disimpulkan bahwa metode sosiodrama berbasis CTL dapat mengembangkan kemandirian anak-anak di TK Smart Kindergarten. Kata kunci: Kemandirian Anak Usia Dini, Metode Sosiodrama Berbasis CTL
\end{abstract}

\footnotetext{
${ }^{1}$ srikartinidewiastuti26@gmail.com

${ }^{2}$ Dosen UPI Kampus Cibiru

${ }^{3}$ Dosen UPI Kampus Cibiru
} 


\section{A. PENDAhULUAN}

Kemandirian adalah kemampuan untuk melakukan sesuatu demi dirinya sendiri. Manusia meraih kemandiriannya dengan melakukan upaya agar mampu melakukan sesuatu tanpa bantuan dari siapapun sehingga kemandirian bagi anak harus diraih secara langsung. Orang dewasa yang terus menerus memberikan bantuan justru menjadi penghambat. Seperti yang dikemukakan oleh Siswanto (2010, hlm. 52) Pendidikan mandiri adalah pendidikan kepada anak kita agar ia mempunyai sikap mau mengusahakan dan berbuat sesuatu atas kesadaran dan usaha sendiri. Ia tidak mudah menggantungkan kepada orang lain. Bukhari (2014, hlm. 1) mengungkapkan bahwa kemandirian anak adalah modal dari kreativitas, kemajuan, dan daya tahan keberlangsungan hidup (survival).

Sementara, ketidakmandirian membentuk ketergantungan pada orang lain dan menghambat kemajuan. Ketika anak tidak dilatih kemandiriannya sejak kecil, maka mereka mungkin hanya tumbuh menjadi follower (pengekor) atau memiliki ketakutan-ketakutan ketika suatu hari mereka harus berpisah dengan orang tuanya, ketakutan mengambil keputusan dan lain-lain. Sejak kecil semua anak menyukai kemandirian. Kemandirian itu diekspresikan dengan rasa ingin tahu yang besar, dan tidak takut dengan kesulitan.

Sagala (dalam Faridli, dkk, 2014, hlm. 39) mengungkapkan sosiodrama merupakan metode mengajar yang mendramatisasikan suatu situasi sosial yang mengandung suatu problem, agar peserta didik dapat memecahkan suatu masalah yang muncul dari dari suatu situasi sosial. Sosiodrama digunakan untuk memberikan pemahaman dan penghayatan akan masalah-masalah sosial serta mengembangkan kemampuan siswa untuk memecahkanya. Kesan yang muncul ketika siswa mengikuti kegiatan pembelajaran dengan metode konvensional adalah siswa menjadi objek dari materi yang disampaikan oleh guru. Sedangkan metode sosiodrama memberikan kesempatan kepada siswa untuk ikut berperan sebagai subjek dan mengembangkan pemahaman yang lebih luas tentang masalah yang dihadapi.

Salah satu metode yang bisa diaplikasikan untuk mengembangkan kemandirian anak dengan menggunakan metode bermain peran. Penerapan metode bermain peran saya pilih dengan alasan: (1) Penggunaan metode bermain peran sebagai salah satu bentuk kegiatan anak yang mempunyai tingkat kemandirian yang tinggi. (2) Metode bermain peran lebih memberikan pengalaman belajar yang banyak kepada anak untuk berlatih karena di dalam metode tersebut ada proses kerjasama dan saling membutuhkan. (3) Dengan kerjasama dalam bermain peran diharapkan lebih sering dilakukan dan hasil akhir dapat meningkat kemandirian dapat tercapai secara baik.

Pembelajaran kontekstual (Contextual Teaching Learning) adalah konsep belajar yang membantu guru mengaitkan antara materi yang diajarkannya dengan situasi nyata peserta didik dan mendorong peserta didik membuat hubungan antara pengetahuan yang dimilikinya dengan penerapannya dalam kehidupan mereka sehari-hari. Depdiknas (dalam Faridli, Harmianto \& Taniredja, 2014, hlm.49).

Suherman, Erman (2003, hlm. 3) berpendapat, "Pembelajaran dengan pendekatan kontekstual (Contextual Teaching and Leaning, CTL) adalah pembelajaran yang dimulai dengan mengambil (mensimulasikan, menceritakan, berdialog, atau tanya jawab) kejadian pada dunia nyata kehidupan sehari-hari yang dialami siswa kemudian diangkat ke dalam konsep yang dibahas. metode CTL (Contextual Teaching Learning) dapat diterapkan pada pendidikan anak usia dini, karena tujuan dari metode ini memiliki tujuh komponen yang dapat mengembangkan aspek perkembangan anak usia dini.

Metode sosiodrama berbasis CTL yaitu kolaborasi dari sosiodrama dan CTL. Metode sosiodrama adalah suatu cara memerankan beberapa peran dalam suatu cerita tertentu yang menuntut integrasi di antara pemerannya. Metode sosiodrama berbasis CTL yang diperankan atau didramatisasikan oleh anak memuat suatu kejadian atau contoh-contoh yang biasa ditemukan dalam kehidupan sehari-hari anak. Metode sosiodrama berbasis CTL sangat berkaitan, karena dengan metode sosiodrama/bermain peran anak dapat melakukan hal-hal atau kegiatan yang diperankan sesuai dengan kegiatan atau pembiasaan sehari-harinya.

Berdasarkan hal tersebut, permasalahan yang dirumuskan ialah sebagai berikut.

1. Bagaimana aktivitas kemandirian anak melalui metode sosiodrama berbasis CTL (Contextual Teaching Learning)? 
2. Bagaimana peningkatan kemandirian anak setelah diterapkannya metode sosiodrama berbasis CTL (Contextual Teaching Learning)?

Berdasarkan rumusan masalah tersebut, peneliti mengambil tujuan penelitian ialah untuk mengetahui proses penerapan metode sosiodrama berbasis CTL dalam meningkatkan kemandirian anak usia dini.

\section{B. METODE}

Dalam penelitian ini penulis menggunakan metode penelitian tindakan kelas. Penggunaan metode didasari untuk meningkatkan sikap propesionalisme guru dalam proses pembelajaran dan melalui refleksi diri dalam upaya memecahkan suatu masalah pembelajaran dengan berbagai tindakan yang terencana. Sebagaimana dikemukakan oleh Sanjaya (2013, hlm. 149) PTK (Penelitian Tindakan Kelas) adalah proses pengkajian masalah pembelajaran di dalam kelas melalui refleksi diri dan upaya untuk memecahkannya dengan cara melakukan berbagai tindakan yang terencana dalam situasi nyata serta menganalisis setiap pengaruh dari tindakan tersebut. Abidin (2012, hal. 217) mengemukakan bahwa "Penelitian tindakan kelas pada dasarnya adalah penelitian yang dilakukan untuk memecahkan masalah, mengkaji langkah permasalahan itu sendiri, dan juga memperbaiki proses pembelajaran secara berulang-ulang".

Penelitian ini dilaksanakan di TK Smart Kindergarten yang berada di Komplek Taman Duta Cileunyi kecamatan Cileunyi Kabupaten Bandung dengan subjek kelas A2 yang berjumlah 9 orang anak. Penelitian ini bertujuan untuk meningkatkan kemandirian anak usia dini khususnya anak usia 4-5 tahun dengan indikator yang meliputi: Anak mampu menyiapkan perlengkapan makan secara mandiri sesuai dengan intruksi dan tertib, Anak mampu mengambil makanan dengan sendiri sesuai takaran dan rapi, Anak mampu membereskan makan secara mandiri dengan rapi dan bersih.

Langkah pelaksanaan pembelajaran dalam kegiatan dengan menggunakan metode sosiodrama berbasis CTL, yaitu saat kegiatan makan bersama. Kegiatan yang terbiasa dilakukan dalam kehidupan sehari-hari anak dapat mengembangkan kemandirian pada anak jika dilakukan tanpa bantuan dan bergantung pada orang tua atau pun orang dewasa yang ada disekitar anak. Orang tua atau orang dewasa yang berada disekitar anak sebaiknya memberikan kesempatan kepada anak untuk melakukan kegiatan yang dapat melatih kemandirian anak. Tidak hanya orang tua atau orang dewasa dirumah namun guru disekolah dalam mengembangkan kemandirian anak sebaiknya memberikan kesempatan pada anak untuk melakukan kegiatan tertentu, misalnya memberikan rasa tanggung jawab pada saat selesai bermain anak diminta untuk mengembalikan alat permainannya ke tempat semula atau dengan memberi arahan pada anak pada saat kegiatan makan yaitu dengan memberi peraturan untuk mengembangkan kemandirian pada saat kegiatan makan bersama seperti mencuci tangan, mengambil peralatan makan, dan mengambil makanan yang akan dimakan, serta membersihkan tempat makan, dan mengembalikan peralatan makan pada tempatnya. Kegiatan tersebut akan membantu anak untuk mandiri dalam kegiatan dasar yang ada dalam kehidupan seharihari. Kegiatan rutin yang dilakukan akan membantu untuk mengembangkan aspek perkembangan anak. Melalui kegiatan makan bersama dapat dijadikan sebagai cara untuk mengembangkan kemandirian pada anak. Untuk memperoleh data mengenai performa aktivitas penilaian yang digunakan yaitu dengan lembar observasi anak dan lembar penilaian performa. Selain itu data pendukung yang digunakan dalam penelitian ini ialah lembar observasi guru, catatan lapangan, dan dokumentasi penelitian.

Tekhnik analisis data yang digunakan ialah tekhnk analisis data kualitatif/deskriptif dimana tekhnik ini menjabarkan dari hasil tekhnik data kuantitatif, rumus yang digunakan yaitu sebagai berikut.

Jumlah nilai yang diperoleh anak

Persentase (\%) ------------- x 100\%

Jumlah anak

Selain itu uji validitas dalam penelitian ini ialah dengan menggunakan tekhnik triangulasi data. 


\section{PEMBAHASAN}

Penelitian yang dilakukan oleh peneliti merupakan hasil implementasi dari perencanaan penelitian tindakan kelas yang telah disusun secara terencana. Penelitian yang dilaksanakan 3 siklus dimana dalam 1 siklusnya terdiri dari 3 tindakan. Temuan yang diperoleh adalah berupa data-data yang dihasilkan selama proses penelitian berlangsung mulai dari siklus I,

siklus II, dan siklus III. Hasil penelitian dideskripsikan kemudian dianalisis dan direfleksi. Refleksi ini dilakukan di akhir siklus untuk mengetahui kelebihan dan kekurangan dari permainan sosiodrama dalam upaya meningkatkan kemandirian anak usia dini sehingga dapat dilakukan perbaikan untuk siklus selanjutnya apabila dari siklus sebelumnya terdapat kekurangan.

Pada Siklus I dilaksanakan dengan tiga tindakan yakni tindakan 1,2 dan 3. Adapun kegiatan yang dilakukan adalah anak mengenal sayuran hijau (bayam) melalui demontrasi. Selain itu anak melakukan sosiodrama melalaui proses kegiatan makan bersama. Yang dilakukan dengan pembiasaan serta memberikan reward yang menarik untuk anak. Hal ini sejalan dengan Thomdike (Sagala, 2006, hlm. 57) yang menyatakan bahwa salah satu pembelajaran yang dilakukan anak yaitu dengan pemberian reward. Pemberian rewadrd ini bertujuan untuk meningkatkan motivasi anak dalam bermain sosiodrama pada saat kegiatan makan bersama Berikut dibawah ini merupakan hasil penilaian performa kemandirian anak melalui penerapan metode sosiodrama berbasis CTL pada siklus I.

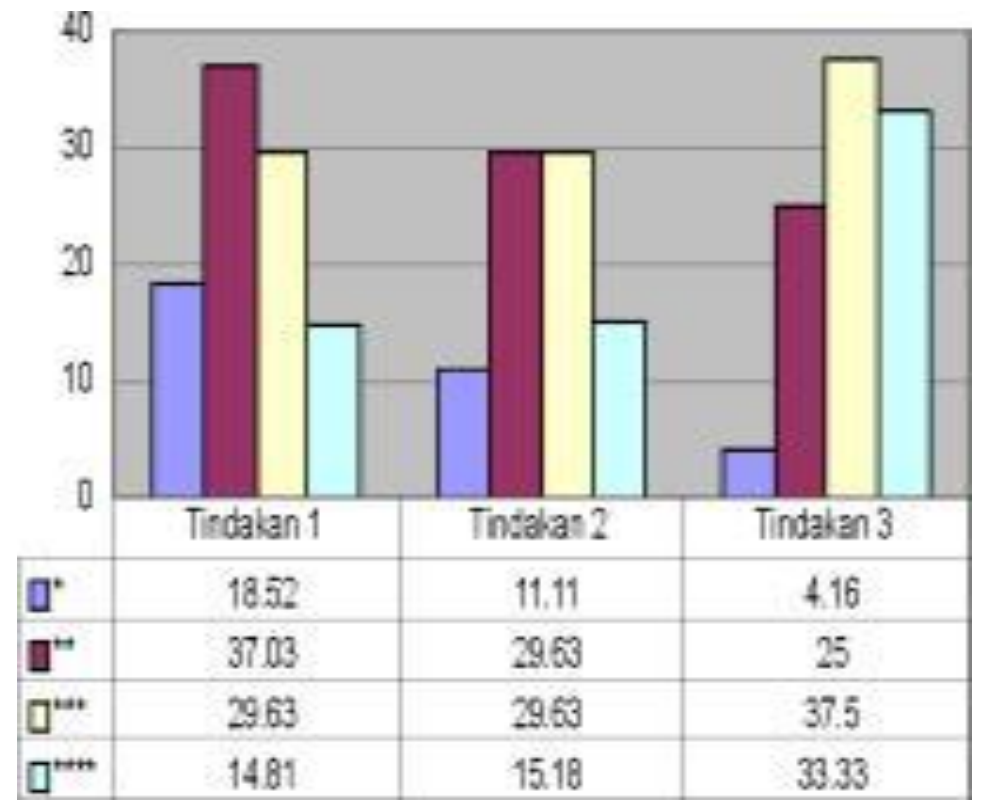

Grafik 4.1

\section{Hasil penilaian performa kemandirian anak melalui penerapan metode sosiodrama} berbasis CTL(Contextual Teaching Learning) pada Siklus I

Berdasarkan grafik 4.1 di atas dapat diketahui bahwa kemampuan kemandirian anak pada Siklus I terdiri dari tiga tindakan yakni tindakan 1, tindakan 2, dan tindakan 3. Adapun kemandirian anak pada siklus I belum maksimal terlihat dari jumlah anak mendapat bintang empat masih sedikit., sehingga perlu untuk lebih ditingkatkan.

Pada tindakan 1 anak yang mendapatkan bintang empat baru mencapai 14,81\%, pada tindakan 1 ini kemampuan kemandirian anak belum meningkat secara optimal, anak yang mendapat bintang dua mencapai $29,63 \%$. Kemudian anak yang mendapat bintang tiga mencapai 37,03\%. Sedangkan anak yang mendapatkan bintang satu mencapai 18,52\%. Pada tindakan 2 diperoleh bahwa anak yang mendapat bintang empat mencapai $15,18 \%$, hal ini bahwa kemampuan kemandirian anak sudah mulai meningkat dari hasil tindakan sebelumnya yaitu tindakan 1, anak yang mendapat bintang tiga mencapai $29,63 \%$, anak yang mendapat bintang dua mencapai $29,63 \%$. Kemudian selanjutnya anak 
yang mendapatkan bintang satu mencapai 11,11\%. Pada tindakan 3 dapat diketahui bahwa anak yang mendapat bintang empat mencapai 33,33\%, pada tindakan ke 3, kemampuan kemandirian anak juga mulai meningkat dari tindakan sebelumnya, anak yang mendapatkan bintang tiga mencapai 37,5\%. Kemudian anak yang mendapatkan bintang dua mencapai 25\%. Sedangkan anak yang mendapat bintang empat mencapai $4,16 \%$. Pada setiap tindaka kemampuan kemandirian anak memang meningkat secara signifikan, namun siklus 1 ini kemampuan kemandirian anak belum maksimal terlihat dari jumlah anak mendapat bintang empat masih sedikit sehingga perlu untuk lebih ditingkatkan.

Pada Siklus II peneliti menyusun rancangan yang lebih inovatif dan menarik pada siklus kedua peneliti merancang kegiatan yang akan diberikan kepada anak yaitu tentang makanan kesukaan, anakanak ditugaskan untuk membawa makanan kesukaannya dari rumah, sehingga hal tersebut membuat anak- anak bersemangat untuk membawa bekal dari rumah dengan aneka makanan yang beragam. Kemudian anak-anak diberikan pemahaman mengenai sikap kemandirian, bahwasannya anak harus membawa bekalnya sendiri tanpa bantuan orang tuanya, sesuai dengan capaian perkembangan kemandirian anak, anak mampu mengambil makanan dengan sendiri. Pendapat ini sejalan dengan Subroto (dalam Wiyani, hlm. 27, 2015) yang mengartikan kemandirian sebagai kemampuan anak untuk melakukan aktivitas sendiri atau mampu berdiri sendiri dalam berbagai hal. Dengan adanya kemandirian, anak tidak akan pernah bergantung pada orang lain, kemandirian yang terbiasa sejak dini akan terbawa hingga ia dewasa nanti. Anak perlu dibiasakan untuk melakukan suatu pekerjaan sendiri, karena dengan begitu anak akan merasa bangga dengan kemampuan yang dimilikinya. Maka dalam penelitian ini peneliti memberikan arahan bagaimana cara makan yang benar ntuk melatih kemandirian anak hendaknya membimbing anak agar mau melakukan kegiatan makan dengan cara yang benar dan mandiri tanpa bergantung kepada orang lain. Agar anak tidak bergantung dengan orang lain atau mandiri sebaiknya anak diberikan kegiatan rutin seperti dalam hal kegiatan makan bersama yang dapat membentuk sikap kemandirian. Temuan esensial pada siklus ini yaitu (1) Saat guru mengkondisikan anak untuk mendengarkan penjelasan aturan pada saat kegiatan makan masih saja ada anak yang belum bisa duduk tenang dan berebut ingin duduk dekat bu guru. (2) Terdapat satu orang anak yang susah sekali makan, dengan alasan bosan, tetapi dengan cara guru mendekati dan memberikan pemahaman anak tersebut akhirnya mau makan. Berdasarkan temuan esensial tersebut peneliti melakukan perbaikan dengan peningkatan kembali tingkat pengkondisian anak dan memperhatikan alokasi waktu dan tingkat kesulitan yang dihadapi oleh anak pada saat bermain sosiodrama dilakukan. Adapun hasil penilaian performa kemandirian anak melalui penerapan metode sosiodrama berbasis CTL pada siklus II sebagai berikut.

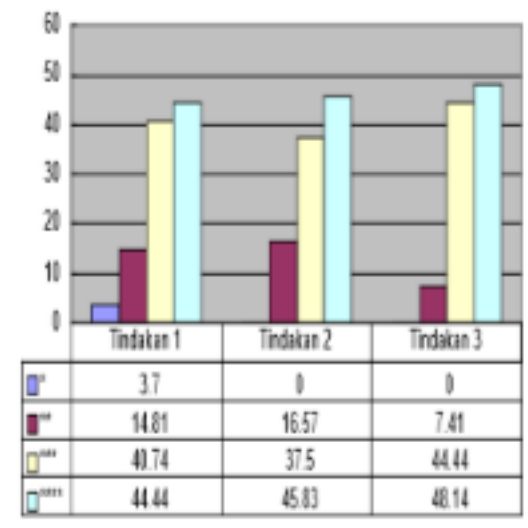

\section{Grafik 4.2 Hasil penilaian performa kemandirian anak melalui penerapan metode sosiodrama berbasis CTL pada Siklus II}

Berdasarkan grafik 4.2 di atas dapat diketahui bahwa kemampuan kemandirian anak pada Siklus II terdiri dari tiga tindakan yakni tindakan 1, tindakan 2, dan tindakan 3. Pada tindakan 1 anak yang mendapatkan bintang empat mencapai $44.44 \%$, anak yang mendapatkan bintang tiga mencapai $40.74 \%$, anak yang mendapatkan bintang dua $14.18 \%$, anak yang mendapatkan bintang satu $3.7 \%$. 
Pada tindakan ke 2, anak yang mendapat bintang empat mencapai $45.83 \%$, anak yang mendapatkan bintang tiga $37.5 \%$, kemudian anak yang mendapatkan bintang dua $16.57 \%$. Sedangkan anak yang mendapatkan bintang satu 0\%. Pada tindakan 3, anak yang mendapat bintang empat mencapai 48.14\%, anak yang mendapatkan bintang tiga $44.44 \%$, anak yang mendapatkan bintang dua $7.41 \%$, anak yang mendapatkan bintang satu $0 \%$. Pada siklus II ini kemampuan kemandirian anak melalui sosiodrama meningkat secara signifikan dari siklus sebelumnya yakni siklus II.

Pada Siklus III dilaksanakan dengan tiga tindakan yakni tindakan 1,2 dan 3. Adapun kegiatan yang dilakukan adalah anak mengetahui makanan sehat (empat sehat lima sempurna). Selain itu anak melakukan sosiodrama berbasis CTL melalaui proses kegiatan makan bersama. Dengan bermain peran anak terlihat lebih aktif dalam melakukan segala aktivitasnya, anak dapat memilih sendiri peran yang ingin dimainkan. Dengan melakukan sosiodrama berbasis CTL yang diperankan atau didramatisasikan oleh anak memuat suatu kejadian atau contoh-contoh yang biasa ditemukan dalam kehidupan sehari- hari anak. Selain itu dalam memainkan peran pun harus dihayati, seperti yang di ungkapkan Heriawan, A (2012, hlm. 141) bahwa metode sosiodrama/bermain peran merupakan suatu metode mengajar dimana siswa dapat mendramatisasikan tingkah laku atau ungkapan gerak gerik wajah seseorang dalam hubungan sosial antar manusia. Metode sosiodrama berbasis CTL sangat berkaitan, karena dengan metode sosiodrama/bermain peran anak dapat melakukan hal-hal atau kegiatan yang diperankan sesuai dengan kegiatan atau pembiasaan sehari-harinya. Pendapat ini sejalan dengan Depdiknas (dalam Faridli, Harmianto \& Taniredja, 2014, hlm.49) CTL (Contextual Teaching Learning) adalah konsep belajar yang membantu guru mengaitkan antara materi yang diajarkannya dengan situasi nyata peserta didik dan mendorong peserta didik membuat hubungan antara pengetahuan yang dimilikinya dengan penerapannya dalam kehidupan mereka sehari-hari. Pada siklus III ini merupakan refleksi dari siklus sebelumnya, sehingga hal tersebut dapat terjadi, dari setiap indikator mengalami peningkatan yang cukup signifikan. Adapun hasil penilaian performa kemandirian anak melalui penerapan metode sosiodrama berbasis CTL pada siklus III sebagai berikut.

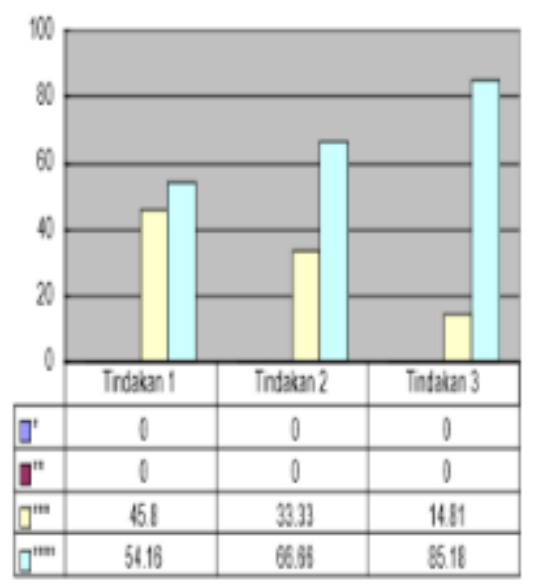

Grafik 4.3

\section{Hasil penilaian performa kemandirian anak melalui penerapan metode sosiodrama berbasis CTL pada Siklus III}

Berdasarkan grafik 4.3 di atas dapat diketahui bahwa kemampuan kemandirian anak pada Siklus III terdiri dari tiga tindakan yakni tindakan 1, tindakan 2, dan tindakan 3. Pada tindakan 1 anak yang mendapatkan bintang empat mencapai 54,16\%, secara keseluruhan pada tindakan 1 siklus III ini kemampuan kemandirian anak sudah meningkat. Anak yang mendapatkan bintang tiga mencapai $45,8 \%$, anak yang mendapatkan bintang dua $0 \%$, anak yang mendapatkan bintang satu $0 \%$. Pada tindakan ke 2, anak yang mendapat bintang empat mencapai 66,66\%, anak yang mendapatkan bintang tiga 33,33\%, kemudian anak yang mendapatkan bintang dua $0 \%$. Sedangkan anak yang mendapatkan bintang satu $0 \%$. Pada tindakan 3 , anak yang mendapat bintang empat mencapai $85,18 \%$, anak yang mendapatkan bintang tiga $14,81 \%$, anak yang mendapatkan bintang dua $0 \%$, anak yang mendapatkan bintang satu $0 \%$. 
Pada siklus III ini kemampuan kemandirian anak melalui sosiodrama meningkat secara signifikan dari siklus sebelumnya yakni siklus I dan II. Anak mengalami peningkatan dalam menyiapkan perlengkapan makan sendiri, mengambil makanan sendiri, dan membereskan perlengkapan makan secara mandiri, pada proses kegiatan makan bersama melalui melalui bermain peran Sehingga bukan hanya kemampuan kemandirian anak saja yang meningkat, namun anak juga lebih antusias dan luwes dalam melakukan sosiodrama pada saat makan bersama.

Berdasarkan paparan di atas, akan dipaparkan peningkatan capaian kemandirian anak mulai dari Siklus I sampai Siklus III. Berikut adalah hasil performa kemandirian anak pada Siklus I, II, dan III yang tertera pada grafik 4.4 di bawah ini.

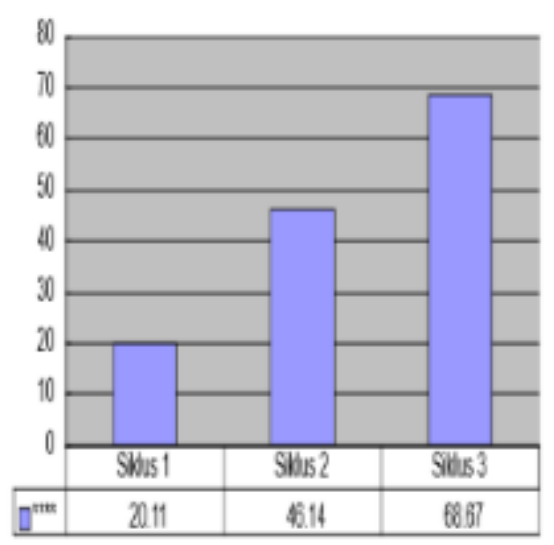

\section{Grafik 4.4 Peningkatan capaian kemampuan kemandirian anak Siklus I, II, dan III.}

Berdasarkan grafik 4.4 di atas menunjukkan bahwa kemampuan kemandirian anak setelah diterapkannya metode sosiodrama berbasis CTL mengalami peningkatan, hal ini terlihat dari capaian perkembangan kemampuan kemandirian anak pada tiap siklus. Pada Siklus I anak yang mendapat bintang empat mencapai $20,11 \%$. Pada Siklus II anak yang mendapat bintang empat mencapai 46,14\%. Sedangkan pada Siklus III anak yang mendapat bintang empat mencapai 68,67\%. Dalam hal ini anak sudah mampu menyiapkan perlengkapan makan secara mandiri sesuai dengan intruksi dan tertib, anak sudah mampu mengambil makanan yang akan dimakan dengan sendiri sesuai takaran dan rapi, kemudian anak sudah mampu membereskan perlengkapan makan secara mandiri dengan rapi dan bersih. Kemampuan yang telah dicapai oleh anak tersebut merupakan indikator pencapaian dalam meningkatkan kemampuan kemandirian anak. Artinya dapat disimpulkan bahwa penerapan metode sosiodrama untuk dapat meningkatkan kemandirian anak berkembang dengan meningkat secara signifikan.

Berdasarkan hasil penelitian pada kemandirian anak dari siklus I sampai dengan siklus III, terjadi peningkatan dimana anak mampu menyiapkan perlengkapan makan dengan mandiri, anak mampu mengambil makan dengan sendiri, dan anak mampu membereskan perlengkapan makan secara mandiri. Seperti penelitian yang dilakukan sebelumnya oleh Sunarni (2012) Dalam penelitiannya yang berjudul Upaya Peningkatan Kemandirian Anak Melalui Metode Bermain Peran (Role Playing). Kemampuan kemandirian anak dapat meningkat dengan melalui metode sosiodrama. Metode sosiodrama berbasis CTL yang diperankan atau didramatisasikan oleh anak memuat suatu kejadian atau contoh-contoh yang biasa ditemukan dalam kehidupan sehari-hari anak. Selain itu dalam memainkan peran pun harus dihayati, seperti yang di ungkapkan Heriawan, A (2012, hlm. 141) bahwa metode sosiodrama/bermain peran merupakan suatu metode mengajar dimana siswa dapat mendramatisasikan tingkah laku atau ungkapan gerak gerik wajah seseorang dalam hubungan sosial antar manusia. Hanafiah, N (2012, hlm. 67) menyatakan bahwa CTL merupakan suatu proses pembelajaran holistik yang bertujuan untuk membelajarkan peserta didik dalam memahami bahan ajar secara bermakna (meaningfull) yang dikaitkan dengan konteks kehidupan nyata, dengan metode sosiodrama/bermain peran anak dapat melakukan hal-hal atau 
kegiatan yang diperankan sesuai dengan kegiatan atau pembiasaan sehari-harinya.

Peningkatan kemandirian anak melalui metode sosiodrama berbasis CTL dapat diketahui melalui hasil dari penilaian performa. Pada indikator performa yang meliputi: Anak mampu menyiapkan perlengkapan makan dengan mandiri, Anak mampu mengambil makanan secara mandiri, Anak mampu membereskan perlengkapan makan. Indikator tersebut dijadikan oleh peneliti sebagai acuan dalam peningkatan kemandirian anak. Dalam 3 siklus dan masing-masing siklus terdiri dari 3 tindakan. Hasil performa aktivitas dan hasil peningkatan kemandirian anak pada kelompok A2 di TK Smart Kindergarten dengan menggunakan metode sosiodrama berbasis CTL.

\section{KESIMPULAN}

Aktivitas yang merupakan pembiassan melalui kegiatan makan bersama dengan menggunakan metode sosiodrama berbasis CTL dapat meningkatkan kemandirian anak. Dimulai dengan guru memfasilitasi anak untuk melakukan sosiodrama, anak aktif berperan sebagai ayah, ibu, kaka, dan adik. Dalam pembiasaan ini anak mendapatkan hasil pembelajaran yang diperoleh dari kerjasama dengan orang lain, dari berbagi antar teman, dan teman kelompok lainnya. Dengan melakukan pembiasaan ini, sehingga anak dapat memiliki kemandirian sejak usia dini. Pembiasaan yang dimaksudkan misalnya pembiasaan dalam hal anak menyiapkan perlengkapan makan, anak membereskan perlengkapan makan, hal tersebut masih dalam pengawasan seorang pendidik. Kemandirian anak usia dini di TK Smart Kindergarten pada umumnya sudah berkembang. Hal ini sesuai dengan indikator ketercapaian perkembangan kemandirian anak usia dini yang tercantum dalam kurikulum tingkat satuan pendidikan TK/RA. Dua dari sembilan orang anak yang terdapat di kelas tersebut belum mencapai indikator perkembangan secara menyeluruh, tujuh orang anak usia dini yang terdapat di TK Smart Kindergarten sudah memiliki kemandirian.

\section{REFERENSI}

Abidin, Y. (2011). Penelitian Pendidikan Dalam Gamitan Pendidikan Dasar dan PAUD. Bandung: Rizqi Press.

Bukhari, I. (2014). Mengajarkan Kemandirian Kepada Anak. Bandung: Khazanah

Intelektual Departemen Pendidikan Nasional. (2002) Contextual Teaching and Learning. Dirjen Pend. Dasar dan Menengah, DPLP.

Faridli, Harmianto, \& Taniredja. (2014). Model-Model Pembelajaran Inovatif dan Efektif. Bandung: Alfabeta

Hanafiah, N., dkk. (2012). Konsep Strategi Pembelajaran. Bandung: Refika Aditama.

Heriawan, A., dkk. (2012). Metodologi Pembelajaran Kajian Teoretis Praktis. Banten: Pembinaan Pengembangan Guru.

Johnson, (2014). CTL Teaching Bandung: Kifa Salahudin, A. (2015). Tindakan Kelas. Pustaka Setia

Suherman, E. (2003). Strategi Pembelajaran Matematika Kontemporer. Bandung: JICA.

Sunarni, (2012). Upaya Peningkatan Kemandirian Anak Melalui Metode Bermain Peran (Role Playing) Pada Anak Usia Dini Di TK Pertiwi Karanganyar Kecamatan Plup ' Kabupaten Sragen Tahun Ajaran 2011/2012. (Skripsi). UMS

Sanjaya, Wina. (2013). Penelitian Pendidikan. Jakarta: kencana prenada media group.

Siswanto, Wahyudi. 2010. Membentuk kecerdasan spiritual anak. Jakarta: Sinar Grafika Offset. 